\title{
Seasonal fluctuations in airway responsiveness in elite endurance athletes
}

\author{
Howard B Hemingson BSc, Beth E Davis BSc, Donald W Cockcroft MD FRCPC
}

\begin{abstract}
HB Hemingson, BE Davis, DW Cockcroft. Seasonal fluctuations in airway responsiveness in elite endurance athletes. Can Respir J 2004;11(6):399-401.
\end{abstract}

BACKGROUND: It has been suggested that exposure to winter training conditions (irritants in indoor facilities and/or cold, dry air in the outdoors) can increase airway responsiveness in elite endurance athletes.

OBJECTIVES: It has yet to be elucidated whether elite endurance athletes experience seasonal fluctuations in their airway responsiveness. METHODS: Eighteen members of a varsity cross-country running team underwent screening procedures and five members were enrolled in the study. Each athlete completed a respiratory and training questionnaire, and underwent allergy skin prick testing. Airway responsiveness was evaluated using a methacholine challenge on four occasions. RESULTS: The participants demonstrated a significant (more than twofold) increase in airway responsiveness $(\mathrm{P}=0.0496)$ during the first winter evaluation compared with the autumn baseline. The second winter evaluation still showed an increase but it was not statistically significant. Airway responsiveness had returned to baseline (autumn) values at spring testing.

CONCLUSION: Elite endurance athletes experience seasonal fluctuations in airway responsiveness. The specific stimuli that cause this are unknown, but it is speculated to be due to exposure to cold, dry air and/or inhaled irritants that may be present in indoor training facilities.

Key Words: Airway responsiveness; Athletes; Cold air exposure; Seasonal variability

lite endurance athletes have a higher prevalence of respiraEtory problems than the general population $(1,2)$. This is thought to be related to environmental factors. Of particular interest to the present investigation is the observed high prevalence of airway hyperresponsiveness in winter athletes (1). Very few studies have investigated whether exercise in cold, dry air increases airway responsiveness to pharmacological challenge. Previous studies (3) have focused only on acute cold air exposure and found no change in nonasthmatics. To our knowledge, there have been no longitudinal studies examining the effects of cold air exposure during exercise on airway responsiveness in athletes.

\section{METHODS}

\section{Subjects}

Eighteen members of the University of Saskatchewan varsity cross-country running team ( 10 women, eight men) agreed to participate in the present study. Subjects had to train during the study, have no allergies to common airborne allergens (determined by a skin prick test; wheal size greater than $3 \mathrm{~mm}$ ) and not be taking any anti-inflammatory asthma medication. The study was

\section{Variations saisonnières de la réactivité des voies aériennes chez les athlètes d'endurance d'élite}

CONTEXTE : Il semblerait que l'exposition aux conditions d'entraînement en hiver (irritants dans les installations intérieures ou air froid et sec à l'extérieur) fasse augmenter la réactivité des voies aériennes chez les athlètes d'endurance d'élite.

OBJECTIF : Déterminer si les athlètes d'endurance d'élite connaissent des variations saisonnières de la réactivité des voies aériennes.

MÉTHODE : Dix-huit membres d'une équipe universitaire de course de fond ont été soumis à des analyses de dépistage et cinq membres ont été retenus. Chaque athlète a rempli un questionnaire sur son état de santé respiratoire et sur son entraînement, en plus de subir des tests d'allergie par piqûre. La réactivité des voies aériennes a été évaluée à l'aide d'une épreuve de provocation à la méthacholine, effectuée quatre fois.

RÉSULTATS : Une réactivité importante des voies aériennes, en fait plus du double $(\mathrm{P}=0,0496)$ de celle enregistrée au départ, l'automne précédent, a été notée chez les participants au cours de la première évaluation réalisée en hiver. La deuxième évaluation également effectuée en hiver a révélé une autre augmentation, mais elle n'était pas statistiquement significative. La réactivité des voies aériennes est revenue aux valeurs initiales (automne) au moment du test effectué au printemps. CONCLUSION : Les athlètes d'endurance d'élite connaissent des variations saisonnières de la réactivité des voies aériennes. On ne sait pas encore quels agents particuliers provoquent le phénomène, mais l'exposition à l'air froid et sec et l'inhalation d'irritants dans les installations intérieures pourraient être mises en cause.

approved by the University Committee on Ethics in Human Research and each subject provided informed written consent.

\section{Study design}

The athletes were initially evaluated in October (baseline/autumn) and had subsequent evaluations in January (test 1/winter), March (test 2/winter) and May (test 3/spring). The total duration of the study was eight months. During baseline evaluations, a skin prick test and a questionnaire of general health, respiratory symptoms and running history were conducted to determine subject eligibility. Training logs were maintained by the subjects throughout the study. Baseline spirometry and a methacholine challenge were conducted at each evaluation. Subjects were withdrawn from the study if they discontinued training, and were excluded from an evaluation if they showed signs of a respiratory infection within four weeks of the evaluation.

\section{Spirometry and methacholine challenge}

Expiratory flows were determined with a pneumotachograph and computer software (KoKo Trek Spirometer and software, PDS 
TABLE 1

Subject characteristics

\begin{tabular}{|c|c|c|c|c|c|c|c|}
\hline Subject & Sex & Age (years) & $\begin{array}{c}\text { Baseline } \mathrm{PC}_{20} \\
(\mathrm{mg} / \mathrm{mL})\end{array}$ & $\begin{array}{l}\text { Baseline } \\
\text { FEV }_{1} \text { (L) }\end{array}$ & Training (years) & $\begin{array}{l}\text { Winters } \\
\text { training }\end{array}$ & Progress in study \\
\hline 1 & M & 22 & 35 & 4.26 & 9 & 4 & Completed study \\
\hline 2 & $\mathrm{~F}$ & 23 & 16 & 3.66 & 8 & 8 & Withdrawn after test 2 ; discontinued training \\
\hline 3 & $\mathrm{~F}$ & 21 & 92 & 3.45 & 6 & 6 & Completed study \\
\hline 4 & $\mathrm{M}$ & 20 & 28 & 3.91 & 6 & 5 & Withdrawn after test 1 ; discontinued training \\
\hline 5 & $\mathrm{~F}$ & 19 & 159 & 3.42 & 10 & 10 & Completed study: missed test 2 ; illness \\
\hline \multicolumn{2}{|c|}{ Average (SEM) } & $21.0(1.6)$ & 47.2 & $3.74(0.31)$ & $7.8(1.8)$ & $6.6(2.4)$ & \\
\hline
\end{tabular}

F Female; FEV 1 Forced expired volume in $1 \mathrm{~s}$; $M$ Male; $P C_{20}$ Provocative concentration of methacholine causing a $20 \%$ fall in FEV 1

TABLE 2

Weather and training characteristics

\begin{tabular}{lccc}
\hline & Phase 1 & Phase 2 & Phase 3 \\
\hline Seasonal condition & Autumn & Winter & Spring \\
${\text { Temperature* }\left({ }^{\circ} \mathrm{C}\right)(\mathrm{SEM})}^{11.4(6.1)}$ & $-9.3(7.5)$ & $7.2(6.3)$ \\
Vapour pressure* $(\mathrm{kPa})(\mathrm{SEM})$ & $0.92(0.31)$ & $0.30(0.15)$ & $0.69(0.21)$ \\
Average weekly time training (min) & & & \\
Total outdoor (SEM) & $319(140)$ & $218(83)$ & $265(112)$ \\
Near maximal effort (SEM) & $59(31)$ & $15(21)$ & $59(55)$ \\
Total indoor (SEM) & 0 & $68(50)$ & 0 \\
Near maximal effort (SEM) & 0 & $52(29)$ & 0 \\
\hline
\end{tabular}

*Temperatures and vapour pressures are daily averages

Instrumentation, USA) according to the American Thoracic Society guidelines (4). Forced expired volumes in $1 \mathrm{~s}\left(\mathrm{FEV}_{1}\right)$ were measured in triplicate. The airway responsiveness to methacholine was determined using a standardized method (5). Methacholine challenges were administered in aerosol form during a 2 min tidal respiration interval. Aerosols were generated using a nebulizer (Bennett Twin, Puritan-Bennett Co, USA) calibrated to deliver an output of $0.13 \mathrm{~mL} / \mathrm{min}$. $\mathrm{FEV}_{1}$ maneuvers were performed $30 \mathrm{~s}$ and $90 \mathrm{~s}$ after each inhalation. The procedure began with an isotonic saline solution followed by methacholine which doubled in concentration with every dose. The procedure continued until the subject showed a $20 \%$ drop in $\mathrm{FEV}_{1}$ or the maximum concentration of $256 \mathrm{mg} / \mathrm{mL}$ was reached. The follow-up challenges used an identical concentration progression as the baseline challenge and subjects were tested at the same time of day throughout the study $\pm 2 \mathrm{~h}$. The subjects were advised to avoid strenuous physical activity and the use of beta-agonist asthma medication before the test as per guidelines.

\section{Weather conditions}

Meteorological values were obtained for the Saskatoon area (Environment Canada). Average daily temperatures were calculated between 10:00 $\mathrm{h}$ and 19:00 $\mathrm{h}$.

\section{Statistical analysis}

The per cent fall in $\mathrm{FEV}_{1}$ was calculated from the lowest postdiluent $\mathrm{FEV}_{1}$ compared with the lowest post-methacholine $\mathrm{FEV}_{1}$ and the provocative concentration of methacholine causing a $20 \%$ fall in $\mathrm{FEV}_{1}\left(\mathrm{PC}_{20}\right)$ was interpolated (which was preferred) or extrapolated. Follow-up $\mathrm{PC}_{20}$ values were compared with baseline $\mathrm{PC}_{20}$ values using a paired Student's $t$ test $\left(\log _{2}\right.$ values of $\mathrm{PC}_{20}$ were used). $\mathrm{P}<0.05$ was significant.

\section{Subject characteristics}

\section{RESULTS}

Of the 18 athletes screened, only five (two men, three women) were eligible for the study. Of the 13 participants eliminated, five had positive skin prick responses to common airborne allergens, five developed a dose response plateau (immeasurable $\mathrm{PC}_{20}$ ), two quit training immediately after baseline measurements were taken and one was unable to conduct reproducible spirometry.

The average age of the five continuing subjects was $21.0 \pm 1.6$ years and they had been involved in long distance running for $7.8 \pm 1.8$ years (Table 1 ). The number of winter seasons they had trained through was 6.6 \pm 2.4 . All participants were nonsmokers and two subjects occasionally used a beta-agonist before training. The questionnaire did not reveal any chronic respiratory ailments among the participants, but some subjects indicated a persistent cough after occasional indoor track races.

Of the five subjects participating in the study, three completed the entire study (one subject missed the second winter evaluation due to illness) and the remaining two subjects discontinued training due to injury and were withdrawn from the study (one after the first winter evaluation and the other after the second winter evaluation) (Table 1).

Training during the study occurred predominantly in the Saskatoon area and could be grouped into three distinct phases which coincided with the shifts from outdoor training (autumn), to indoor training (winter) and back to outdoor training (spring) (Table 2).

\section{Weather conditions}

Leading up to the baseline measurements in the fall, the average ambient daily temperature was $11.4 \pm 6.1^{\circ} \mathrm{C}$ and the average vapour pressure was $0.92 \pm 0.31 \mathrm{kPa}$. During the winter follow-up evaluations, the average temperature was $-9.3 \pm 7.5^{\circ} \mathrm{C}$ and the average vapour pressure was $0.30 \pm 0.15 \mathrm{kPa}$. After the last winter evaluation and leading up to the spring evaluation, the average ambient temperature was $7.2 \pm 6.3^{\circ} \mathrm{C}$ and the average vapour pressure was $0.69 \pm 0.21 \mathrm{kPa}$ (Table 2).

\section{Expiratory flow and methacholine challenge}

Each subject underwent baseline expiratory flow measurements during each round of testing. The average $\mathrm{FEV}_{1}$ values throughout the study did not differ significantly (baseline: $3.74 \pm 0.31 \mathrm{~L}$; test 1 : 3.68 $\pm 0.21 \mathrm{~L}$; test 2: $3.66 \pm 0.29 \mathrm{~L}$; and test $3: 3.67 \pm 0.33 \mathrm{~L}$ ). The geometric mean $\mathrm{PC}_{20}$ of $47.2 \mathrm{mg} / \mathrm{mL}$ at baseline decreased to $20.4 \mathrm{mg} / \mathrm{mL}$ at the first winter evaluation $(\mathrm{P}=0.0496)$ (Figure 1). At the second winter evaluation, two subjects showed a further 
decrease, while the third subject showed an increase. The geometric mean $\mathrm{PC}_{20}$ was lower than baseline during this evaluation, but the decrease was not statistically significant. Spring methacholine $\mathrm{PC}_{20}$ values had increased from the previous winter evaluation and were comparable with baseline airway hyperresponsiveness.

\section{DISCUSSION}

Due to the small number of athletes used and the lack of controls, this can only be considered a preliminary study. However, the present study showed a significant increase in the athletes' airway responsiveness at the first follow-up challenge during winter. All of the athletes showed this increase to varying degrees. During the second winter evaluation, two of the three subjects showed a further increase in their airway responsiveness. At the spring evaluation, the three remaining athletes airway responsiveness returned to values comparable with their autumn values. No significance was shown at the last two evaluations, but this could be attributed to the small sample size. Nonetheless, the trend of a transient increase in airway responsiveness during the winter can be seen in the three athletes who completed the study.

The present study indicates that the athletes' airway responsiveness may experience seasonal fluctuations in response to varying environmental conditions. Langdeau et al (1) showed that winter athletes had higher airway responsiveness than did summer athletes. This finding would seem to support our observations, but their athletes were randomly tested over a six-month period between December and May (Langdeau JB, personal communication). The design was unable to indicate if any of their athletes experienced a seasonal fluctuation in airway responsiveness. It would have been interesting if testing had occurred throughout the year to determine if fluctuations were present, and whether winter and summer athletes differed in airway responsiveness.

The observational design of the present study prevents any absolute determination of what caused the change in airway responsiveness. During the autumn and spring seasons, the athletes trained solely outdoors under moderately warm conditions. In the winter, training occurred both outdoors (cold, dry air) and inside a sports complex (a synthetic rubberized track surface with warm, dry air and possible airborne irritants). Cold air stresses the airways due to the required warming and humidifying of the air (6), which can lead to possible inflammation $(7,8)$. The inhalation of airborne irritants has also been shown to cause airway inflammation and increase airway responsiveness in swimmers (9) and hockey players (10). It is impossible to state with any certainty which exposure (outdoor versus indoor) was responsible for the observed seasonal change in airway responsiveness. The athletes were exposed predominantly to outdoor conditions and had small, but substantial, indoor exposure. Some subjects reported respiratory distress (coughs that could last more than a week) shortly after an intense workout or race indoors, which supports the suggestion of indoor conditions being able to affect the athletes' airways. In all likelihood, the observed change in airway responsiveness was due to a combination of the exposure to cold, dry air and indoor facility air.

The results of the present study suggest that the exposure of winter training conditions (irritants in indoor facilities and/or

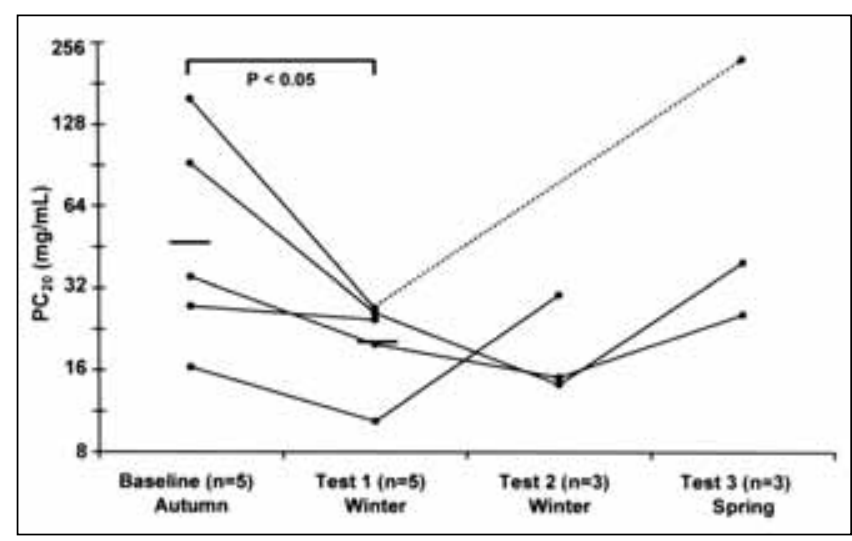

Figure 1) Provocative concentration of methacholine causing a $20 \%$ fall in the forced expired volume in $1 s\left(\mathrm{PC}_{20}\right)$ over time. The evaluations occurred at baseline (October), test 1 (January), test 2 (March) and test 3 (May). Three subjects completed the present study (one missed test 2, dashed line). - Denotes geometric $\mathrm{PC}_{20}$ (baseline $47.2 \mathrm{mg} / \mathrm{mL}$ and test $120.4 \mathrm{mg} / \mathrm{mL}$ ). Bar at top of graph denotes significance between baseline and test 1 values

cold, dry air in the outdoors) causes seasonal fluctuations in airway responsiveness in some athletes. Seasonal fluctuations appear to involve an increase in airway responsiveness during the winter, which is then reversed during the spring. This demonstrates the possible contribution winter training could have on the development of respiratory disorders in endurance athletes. The validity of these observations needs to be augmented by studies with larger sample sizes and ideally, over a longer time frame.

ACKNOWLEDGEMENT: The authors would like to thank all the subjects who participated in the study.

\section{REFERENCES}

1. Langdeau JB, Turcotte H, Bowie DM, Jobin J, Desgagne P, Boulet LP. Airway hyperresponsiveness in elite athletes. Am J Respir Crit Care Med 2000;161:1479-84.

2. Helenius IJ, Tikkanen HO, Sarna S, Haahtela T. Asthma and increased bronchial responsiveness in elite athletes: Atopy and sport event as risk factors. J Allergy Clin Immunol 1998;101:646-52.

3. Tessier P, Ghezzo H, L'Archeveque J, Cartier A, Malo JL. Shape of the dose-response curve to cold air inhalation in normal and asthmatic subjects. Am Rev Respir Dis 1987;136:1418-23.

4. Crapo RO, Casaburi R, Coates AL, et al. Guidelines for methacholine and exercise challenge testing - 1999. This official statement of the American Thoracic society was adapted by the ATS Board of Directors, July 1999. Am J Respir Crit Care Med 2000;161:309-29.

5. Juniper EF, Cockcroft DW, Hargreave FE. Histamine and Methacholine Inhalation Test: Tidal Breathing Method, Laboratory Procedure and Standardisation. Lund: Astro Draco AB, 1994:1-52.

6. McFadden ER Jr, Pichurko BM, Bowman HF, et al. Thermal mapping of the airways in humans. J Appl Physiol 1985;58:564-70.

7. Karjalainen EM, Laitinen A, Sue-Chu M, Altraja A, Bjermer L, Laitinen LA. Evidence of airway inflammation and remodeling in ski athletes with and without bronchial hyperresponsiveness to methacholine. Am J Respir Crit Care Med 2000;161:2086-91.

8. Larsson K, Tornling G, Gavhed D, Muller-Suur C, Palmberg L. Inhalation of cold air increases the number of inflammatory cells in the lung in healthy subjects. Eur Respir J 1998;12:825-30.

9. Helenius I, Rytila P, Sarna S, et al. Effect of continuing or finishing high-level sports on airway inflammation, bronchial hyperresponsiveness, and asthma: A 5-year prospective follow-up study of 42 highly trained swimmers. J Allergy Clin Immunol 2002;109:962-8.

10. Hedberg K, Hedberg CW, Iber C, et al. An outbreak of nitrogen dioxideinduced respiratory illness among hockey players. JAMA 1989;262:3014-7. 


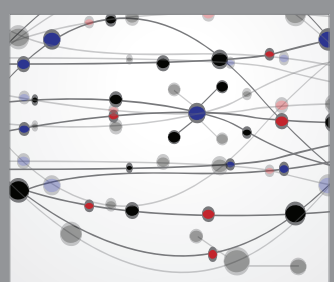

The Scientific World Journal
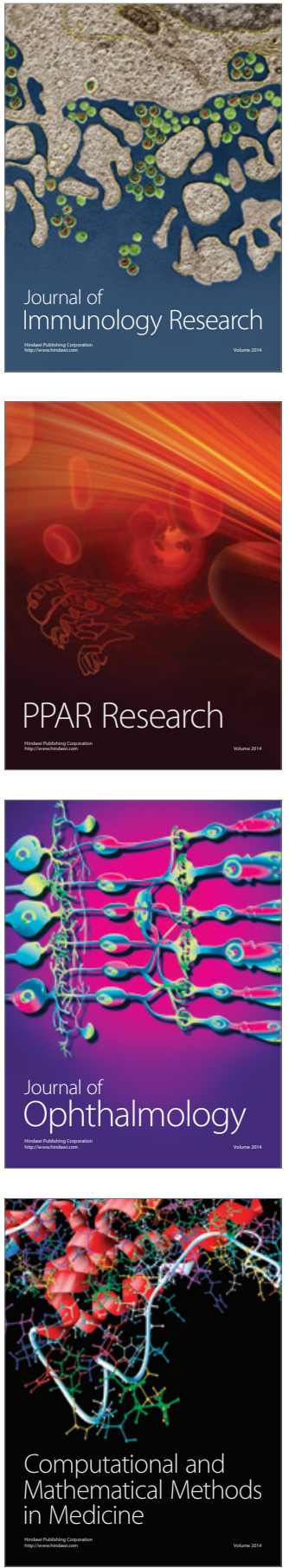

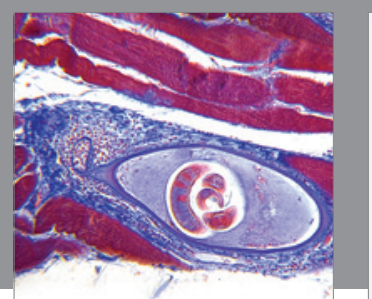

Gastroenterology Research and Practice

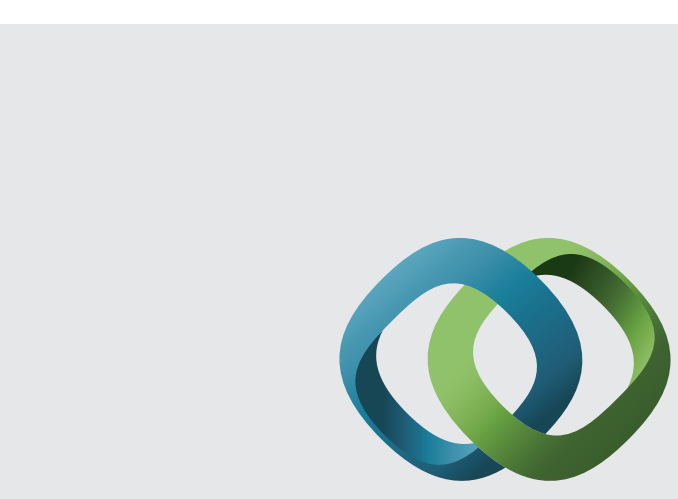

\section{Hindawi}

Submit your manuscripts at

http://www.hindawi.com
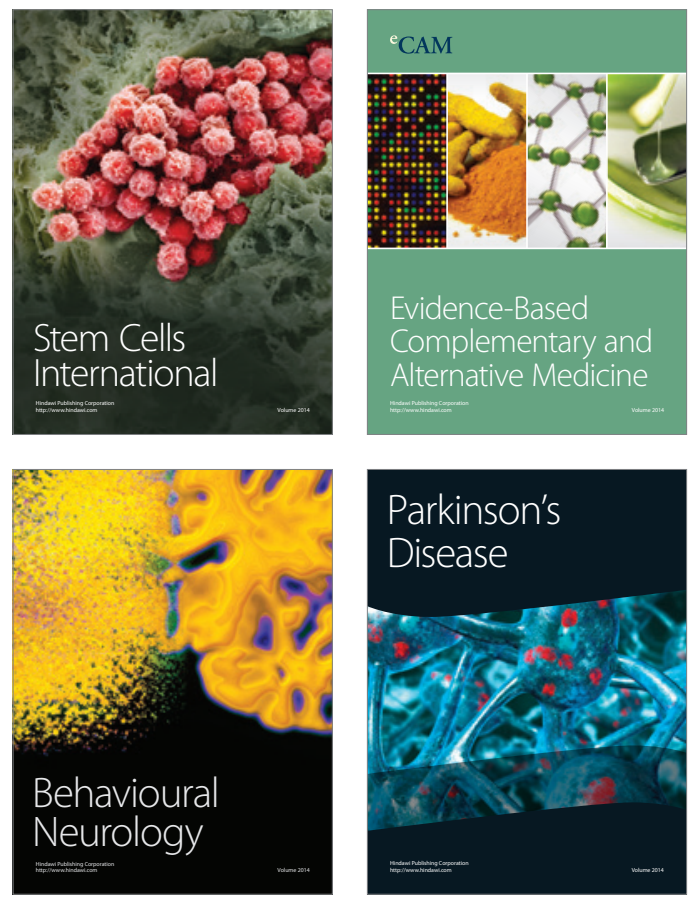
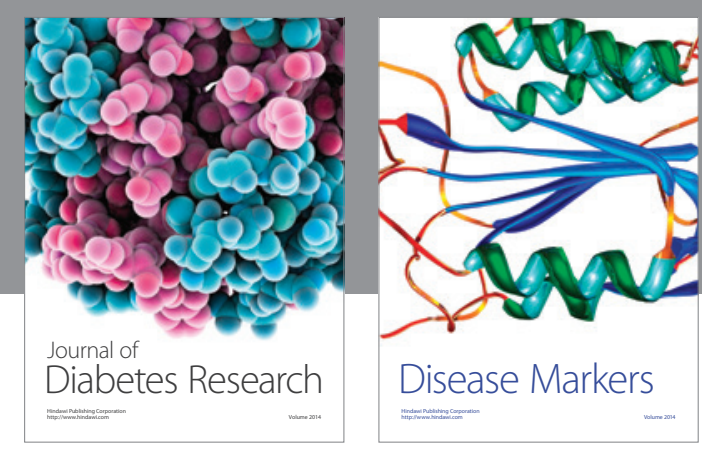

Disease Markers
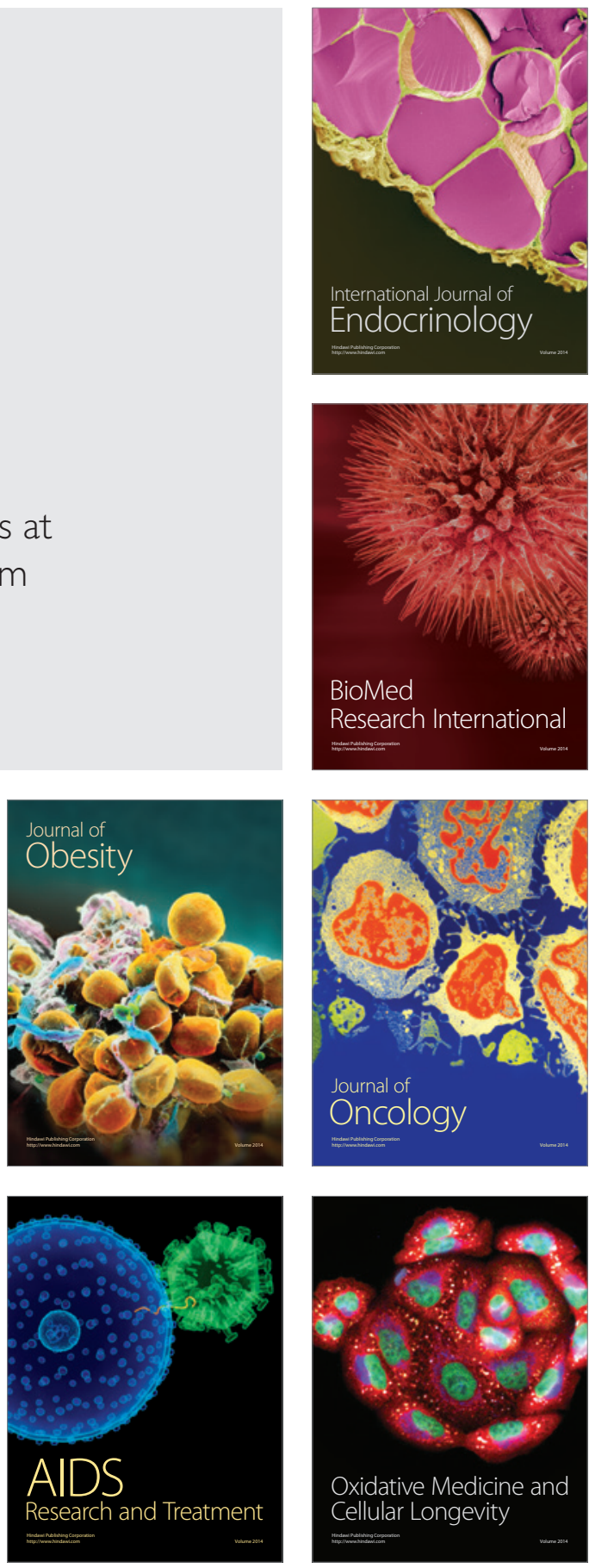